PROF. TAIJI KOU (Orcid ID : 0000-0001-5253-6841)

3

4

5

6

7

8

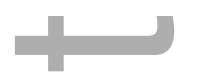

Article type : Short communication

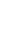
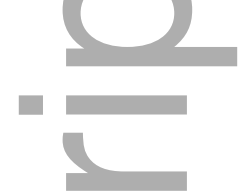

\title{
Soil urease and catalase responses to ozone pollution are affected by the ozone sensitivity of
} wheat cultivars

T.-J. Kou ${ }^{a, b^{*}}$, S.K. Lam ${ }^{\text {b }}$ D.-L. Chen ${ }^{\text {b }} \&$ W.-W. Yu ${ }^{a}$

${ }^{a}$ College of Agriculture, Henan University of Science and Technology, Luoyang, 471003, China

${ }^{\mathrm{b}}$ School of Agriculture and Food, Faculty of Veterinary and Agricultural Sciences, The University of Melbourne, Parkville, VIC 3010, Australia

tralia

\section{(2)}

Abstract Understanding the effects of elevated $\mathrm{O}_{3}\left(\mathrm{EO}_{3}\right)$ on belowground process such as soil enzyme activities is essential to evaluate plant physiological reaction and soil processes (e.g. carbon and nitrogen turnover) under predicted increases in atmospheric $\mathrm{O}_{3}$. In this study, $\mathrm{O}_{3}$-induced changes in soil urease (UA) and catalase activities (CTA) under two contrasting wheat cultivars $\left(\mathrm{O}_{3}\right.$-sensitive vs. $\mathrm{O}_{3}$-tolerant) were investigated using a free-air $\mathrm{O}_{3}$ enrichment $\left(\mathrm{O}_{3} \mathrm{FACE}\right)$ facility in $\mathrm{China} \mathrm{EO}_{3}(60 \mathrm{ppb}$ compared to $40 \mathrm{ppb}$ in ambient $\mathrm{O}_{3}$ ) generally increased $\mathrm{UA}$ under the $\mathrm{O}_{3}$-tolerant cultivar but reduced it under the $\mathrm{O}_{3}$-sensitive cultivar for different soil depths and growth stages. In contrast, the effects of $\mathrm{EO}_{3}$ on CTA were not consistent, and varied with soil depths and growth stages. These results suggest that the $\mathrm{O}_{3}$-sensitivity of wheat cultivars plays an important role in determining the effects of $\mathrm{EO}_{3}$ on soil enzyme activities. The contrasting responses of soil UA and CTA to $\mathrm{EO}_{3}$ may alter the effect of projected increase in tropospheric $\mathrm{O}_{3}$ on soil carbon and nitrogen turnover.

\footnotetext{
* Corresponding author. Tel \& Fax: +86 379 64282340. E-mail: tjkou@ @aliyun.com

This is the author manuscript accepted for publication and has undergone full peer review but has not been through the copyediting, typesetting, pagination and proofreading process, which may lead to differences between this version and the $\underline{\text { Version of Record. Please cite this article as doi: 10.1111/jac.12268 }}$
} 
Keywords soil enzyme; ozone pollution; wheat; ozone-sensitivity; agroecosystem

\section{Abbreviation}

$\mathrm{O}_{3}$ : ozone

$\mathrm{EO}_{3}$ : elevated $\mathrm{O}_{3}$

$\mathrm{AO}_{3}$ : ambient $\mathrm{O}_{3}$

$\mathrm{O}_{3}$ FACE: free-air $\mathrm{O}_{3}$ enrichment

UA: Soil urease

CTA: Soil catalase

\section{Introduction}

Tropospheric $\mathrm{O}_{3}$ is predicted to increase by $40-70 \%$ by the year 2100 from the current level of $25-40$ ppb in the Northern Hemisphere (Biswas et al. 2008, Zeng et al. 2008). The current tropospheric $\mathrm{O}_{3}$ concentration may endanger terrestrial ecosystems through reducing photosynthetic rates, growth and biomass production in many crop, grass and forest species (Wang et al. 2004, Cao et al. 2009, Ashmore et al. 2006, Kou et al. 2009) and ecosystem C storage (Loya et al. 2003, Sitch et al. 2007). It has been widely reported that $\mathrm{O}_{3}$ exposure alters the ratio of root to shoot biomass (Grantz et al. 2006, Chen et al. 2015) and belowground C and N allocation (McCrady and Andersen 2000, Kanerva et al. 2006, Kou et al. 2012). This could affect soil properties (Kou et al., 2014) and structural and functional aspects of soil biodiversity (Dinesh et al.1998, Andersen, 2003) through changing nutrient dynamics in soil profiles (Kou et al. 2014, Wang et al. 2017) and soil microbial community (Sami et al. 2008, Li et al. 2012, Bao et al. 2015). As soil processes are driven by soil organisms (e.g. enzyme, microbial) and their interactions with plants and soil abiotic conditions, $\mathrm{O}_{3}$ pollution has the potential to influence belowground organisms mediating these processes.

Soil enzyme is a sensitive indicator of soil quality and may provide early warning signals in response to climatic and environmental changes (Burns and Dick 2001) via soil biochemical process (e.g. C and $\mathrm{N}$ cycling) regulated by enzymatic reaction ( $\mathrm{Li}$ et al. 2008). UA and CTA are important constituents of soil hydrolytic and oxidoreductase enzymes, respectively. UA is one of the key enzymes that affect $\mathrm{N}$ transformation in soil (Burns and Dick 2001). CTA reflects soil health status in response to environmental stress through decomposing hydrogen peroxide in soil and is involved in humus formation (Burns and Dick 2001). However, the influences of $\mathrm{O}_{3}$ on soil enzymes are not fully 
understood. To our knowledge, studies that reported on soil enzymes response to $\mathrm{EO}_{3}$ from wheat ( $\mathrm{Li}$ et al. 2008, Zheng et al. 2009, Huang et al. 2013, Chen et al. 2015), green vegetable (Shi et al., 2016) and ponderosa pine (Scagel and Andersen 1997) systems were few and showed inconsistent findings. Only four studies reported that the response of $\mathrm{UA}$ to $\mathrm{EO}_{3}$ was either positive (Zheng et al. 2009), negative (Seagel and Andersen 1997, Shi et al. 2016) or neutral (Huang et al. 2013). The effects of $\mathrm{EO}_{3}$ on CTA were generally positive at the wheat late growth stage (Li et al. 2008, Zheng et al. 2009). The limited knowledge on $\mathrm{EO}_{3}$ effects on soil enzyme (UA and CTA) in agroecosystems restricts better understanding on soil belowground processes and $\mathrm{C}$ and $\mathrm{N}$ cycles in response to predicted future higher tropospheric $\mathrm{O}_{3}$ environments.

Wheat (Triticum aestivum L.) is sensitive to $\mathrm{O}_{3}$ (Feng et al. 2008). $\mathrm{EO}_{3}$ was found to reduce photosynthetic rate of wheat and accelerate its senescence, impairing growth and yield (Biswas et al. 2008, Feng et al. 2008, Kou et al. 2012). However, compared to $\mathrm{O}_{3}$-tolerant counterparts, $\mathrm{O}_{3}$-sensitive winter wheat cultivars showed larger reductions in antioxidative capacity, dark respiration (Biswas et al. 2008), photosynthetic rate, stomatal conductance, transpiration rate (Cao et al. 2009), grain yield and individual grain mass (Zhu et al. 2011). This intraspecific variation in growth response to $\mathrm{EO}_{3}$ was also observed in the quantity and quality of $\mathrm{C}$ assimilation allocated to belowground components (McCrady and Andersen 2000, Kou et al. 2012, 2017). Li et al. (2012) found that the $\mathrm{O}_{3}$-tolerance of cultivars affected the component of bacterial and fungal based soil microbial food webs. However, Chen et al. (2015) reported that the $\mathrm{O}_{3}$-sensitivity of cultivars affected wheat biomass allocation, above- and belowground $\mathrm{N}$ uptake and soil $\mathrm{N}$ content but not the nitrifying and denitrifying enzymes at the ripening stage. It is however unclear whether the differential above- and belowground responses to $\mathrm{EO}_{3}$ between $\mathrm{O}_{3}$-sensitive and $\mathrm{O}_{3}$-tolerant cultivars may further influence soil enzyme (e.g. UA, CTA) in different soil depths and growth stages. We therefore investigated the effects of $\mathrm{EO}_{3}$ on UA and CTA in soil grown with $\mathrm{O}_{3}$-sensitive and $\mathrm{O}_{3}$-tolerant wheat cultivars under an $\mathrm{O}_{3}$ FACE fumigation system.

\section{Materials and methods}

Experimental site and ozone fumigation

The experimental site was located in Jiangdu City, Jiangsu province of China $\left(32^{\circ} 35^{\prime} 5^{\prime \prime} \mathrm{N}, 119^{\circ} 42^{\prime} 0^{\prime \prime}\right.$ E). The region's mean annual precipitation and annual temperature are $980 \mathrm{~mm}$ and $14.9{ }^{\circ} \mathrm{C}$, 
respectively. The soil is classified as a Shajiang Aquic Cambiosol (Cooperative Research Group on Chinese Soil Taxonomy, 2001) with a sandy-loamy texture, with $13.6 \%$ clay $(<0.002 \mathrm{~mm})$, bulk density $1.16 \mathrm{~g} \mathrm{~cm}^{-3}$, SOM $18.4 \mathrm{~g} \mathrm{~kg}^{-1}$, total $\mathrm{N} 1.45 \mathrm{~g} \mathrm{~kg}^{-1}$, and $\mathrm{pH} 7.2$ (Kou et al. 2014). An $\mathrm{O}_{3}$ FACE experiment was established in 2007 (Tang et al. 2011) with continuous $\mathrm{O}_{3}$ exposure from March to November each year during the crop growth period in a rice (Oryza sativa $\mathrm{L}$.) -wheat rotation that has been used in this location for over 100 years. Winter wheat was sown in November and harvested in May of the next year, whereas summer rice was transplanted in June and harvested in October. No additional organic matter was incorporated the field except for rice /wheat residuals. Three octagonal rings (14 $\mathrm{m}$ in diameter) were maintained at a mean $\mathrm{O}_{3}$ concentration of $60 \mathrm{ppb}$ from 9:00 am to 18:00 $\mathrm{pm}$ each day except for rainy days (hereinafter referred to as $\mathrm{EO}_{3}$ ) and three control rings at $40 \mathrm{ppb}$ (hereinafter referred to as $\mathrm{AO}_{3}$ ) were used. All of the rings were located $>70 \mathrm{~m}$ apart to avoid $\mathrm{O}_{3}$ cross contamination. Two winter wheat cultivars viz. Yangmai 15 (Y15) and Yannong 19 (YN19), known to be resistant and sensitive to $\mathrm{O}_{3}$ (Zhu et al. 2011), respectively, were grown in two subplots $\left(82 \mathrm{~m}^{2}\right.$ ) of each experimental ring since 2007. This study was conducted during the wheat growing season in 2013. Nitrogen (urea), phosphorus (superphosphate) and potassium (potassium chloride) were applied as 478 $\mathrm{kg} \mathrm{ha}^{-1}, 625 \mathrm{~kg} \mathrm{ha}^{-1}$ and $125 \mathrm{~kg} \mathrm{ha}^{-1}$, respectively. Nitrogen fertilizer was applied prior to sowing, at the jointing stage, and at the booting stage of wheat in a ratio 5:1:4. All phosphorus and potassium fertilizers were applied prior to sowing. Field management closely followed the local agronomic practices

Soil sampling and analyses

Soil samples $(0-5,5-10$ and 10-20 cm) were collected at the jointing stage (April 16), the heading stage (May 1) and the milky stage (May 23). Each soil sample was homogenized from eight soil cores of 2.5 $\mathrm{cm}$ diameter sampled at random locations for each plot. Fresh soil samples were passed through an 8 $\mathrm{mm}$ sieve and stored at $4{ }^{\circ} \mathrm{C}$ until further analyses. UA and CTA were analyzed by the indophenol blue colorimetric method and the potassium permanganate titration method, respectively, according to Burns and Dick (2001).

\section{Statistical analysis}

Statistically significant differences were identified by analysis of variance (ANOVA) using SPSS 11.5 


\section{Results}

Soil urease activity

UA generally increased with soil depth, regardless of cultivar or $\mathrm{O}_{3}$ concentration; it also increased with growth stage, except for the wheat cultivar YN19 grown under $\mathrm{AO}_{3}$ (Fig. 1). $\mathrm{EO}_{3}$ increased UA in the plots grown with Y15, but decreased it in the plots grown with YN19 across all soil layers and key growth stages, respectively, except for non-significant negative effect at the $10-20 \mathrm{~cm}$ soil depth at the milky stage (Fig. 1, Tables 1 and 2). Specifically, $\mathrm{EO}_{3}$ significantly increased UA by $13-45 \%$ in the 0-10 cm layer in Y15 but significantly decreased it by $6-26 \%$ in the $0-20 \mathrm{~cm}$ layer in YN19 at the jointing stage. At the heading stage, $\mathrm{EO}_{3}$ significantly increased $\mathrm{UA}$ by $23-48 \%$ in the $0-20 \mathrm{~cm}$ layer in Y15 but significantly decreased it by $8-25 \%$ in the $0-10 \mathrm{~cm}$ layer in YN19. At the milky stage, $\mathrm{EO}_{3}$ significantly increased UA by $45-50 \%$ in the $0-10 \mathrm{~cm}$ layer in $\mathrm{Y} 15$. For $\mathrm{YN} 19, \mathrm{EO}_{3}$ significantly decreased UA by $7-19 \%$ in the $0-10 \mathrm{~cm}$ layer but significantly increased that by $19 \%$ in the $10-20 \mathrm{~cm}$

Soil catalase activity

CTA responses to $\mathrm{EO}_{3}$ were controlled by cultivar, growth stage and soil depth (Fig. 2, Tables 1 and 2). At the jointing stage, $\mathrm{EO}_{3}$ significantly increased CTA by $13 \%$ and $6 \%$ in the $10-20 \mathrm{~cm}$ layer in $\mathrm{Y} 15$ and YN19, respectively, but only significantly decreased it by $22 \%$ in the $5-10 \mathrm{~cm}$ layers in Y15. At the heading stage, $\mathrm{EO}_{3}$ significantly increased CTA by $6-49 \%$ in the $0-20 \mathrm{~cm}$ layer in $\mathrm{Y}_{15} \mathrm{EO}_{3}$ significantly increased it by $33 \%$ and $40 \%$ in the $0-5 \mathrm{~cm}$ and $10-20 \mathrm{~cm}$ layers, respectively, and significantly decreased it by $15 \%$ in the $5-10 \mathrm{~cm}$ layer in $\mathrm{YN} 19$. At the milky stage, $\mathrm{EO}_{3}$ significantly increased CTA by $34 \%$ in the $0-5 \mathrm{~cm}$ layer and by $36 \%$ in the $10-20 \mathrm{~cm}$ layer and significantly decreased it by $28 \%$ in the $5-10 \mathrm{~cm}$ layer in $\mathrm{Y}_{15} . \mathrm{EO}_{3}$ significantly decreased CTA in the $0-10 \mathrm{~cm}$ layer

\section{Discussion}

146 We found that the responses of $\mathrm{UA}$, an enzyme involved in $\mathrm{N}$ mineralization, to $\mathrm{EO}_{3}$ were affected by This article is protected by copyright. All rights reserved 
the $\mathrm{O}_{3}$-sensitity of wheat cultivar. This indicates that wheat cultivars would play an important role in determining the effects of $\mathrm{EO}_{3}$ on soil UA and its regulating processes. While soil enzymes are mainly associated with microbial and plant $\mathrm{C}$ sources (Burns and Dick 2001), the $\mathrm{O}_{3}$-sensitivity of the wheat cultivar affected the quantity and quality of C input to soil (Kou et al. 2012, 2014) and subsequently the soil biota (Li et al. 2012, Bao et al. 2015) in response to $\mathrm{EO}_{3}$. Since the $\mathrm{C}$ and $\mathrm{N}$ assimilation allocation between above- and belowground was affected by $\mathrm{EO}_{3}$ (Kou et al. 2012, 2017, McCrady and Andersen 2000, Chen et al. 2015), the intraspecific variation in $\mathrm{O}_{3}$ tolerance (Zhu et al. 2011, Huang et al. 2013) altered the substrate availability for enzymes via plant and microbial $\mathrm{C}$ resources. In particular, the contrasting responses of $\mathrm{UA}$ to $\mathrm{EO}_{3}$ (Table 1) were consistent with the findings that $\mathrm{EO}_{3}$ increased the ratios of root to shoot biomass and microbial biomass in Y15 but decreased them in YN19 (Kou et al. 2012, Zhang et al. 2014, Bao et al. 2015). The activities of UA could reflect soil nitrogen-supplying capacity (SNSC) (Burns and Dick 2001). Our findings suggest that SNSC via organic matter decomposition under elevated $\mathrm{O}_{3}$ environments may be enhanced in an $\mathrm{O}_{3}$-tolerant wheat cropping system but reduced in an $\mathrm{O}_{3}$-sensitive one.

Unlike UA, CTA responses to $\mathrm{EO}_{3}$ in each cultivar were not consistent among soil depths or growth stages. This implies that CTA was affected not only by enzyme substrate availability but also by other factors. As an oxidoreductase CTA is also affected by soil environment (abiotic factors) such as the redox potential (Burns and Dick 2001). Since the sources of CTA via assimilation of resources (McCrady and Andersen 2000, Kou et al. 2012) and soil organisms (Li et al. 2012) were changed under $\mathrm{O}_{3}$ stress, the differences in CTA at different soil depth and growth stages under $\mathrm{EO}_{3}$ might be attributed to the differential responding mechanisms of the two wheat cultivars to $\mathrm{EO}_{3}$ (Kou et al. 2012) and soil reducing condition (Chen et al. 2015). The positive responses (10-20 cm layer) of CTA to $\mathrm{EO}_{3}$ in both cultivars would increase the capacity of hydrogen peroxide decomposition, decreasing the toxic effects on soil biology (Wang and Feng 2006). The more negative (0-10 cm layer) responses of CTA in the $\mathrm{O}_{3}$-sensitive than $\mathrm{O}_{3}$-tolerant wheat systems indicates that growing an $\mathrm{O}_{3}$-sensitive cultivar may decrease the ability of hydrogen peroxide decomposition, which may increase the reducing condition in the upper soil layer and $\mathrm{O}_{3}$-stress to the plants. While CTA is highly associated with soil organic matter content, as is UA with N mineralization (Burns and Dick 2001), the contrasting responses of UA and CTA to $\mathrm{EO}_{3}$ between the $\mathrm{O}_{3}$-tolerant and $\mathrm{O}_{3}$-sensitive cultivars would likely affect soil $\mathrm{C}$ and $\mathrm{N}$ cycling. 


\section{Conclusions}

Our findings indicate that $\mathrm{EO}_{3}$ can affect soil UA and CTA in wheat cropping systems, but the effect is strongly dependent on the $\mathrm{O}_{3}$ sensitivity of the wheat cultivar. The responses of UA and CTA to $\mathrm{EO}_{3}$ were mainly positive for an $\mathrm{O}_{3}$-tolerant cultivar but negative for an $\mathrm{O}_{3}$-sensitive cultivar. This study highlights the need for further investigation on the impacts of $\mathrm{O}_{3}$ on soil enzyme activities to better explain the belowground processes associated with $\mathrm{C}$ and $\mathrm{N}$ cycling under projected rising tropospheric $\mathrm{O}_{3}$.

\section{Acknowledgement}

This work was supported by the National Natural Science Foundation of China (grant no. 41003030), 2015TTD002), Open Research Fund Program of State Key Laboratory of Soil and Sustainable

\section{Reference}

Andersen, C.P., 2003: Source-sink balance and carbon allocation below ground in plants exposed to ozone. New Phytol. 157, 213-228.

Ashmore, M.R., S. Toet, and L.D. Emberson, 2006: Ozone-a significant threat to future world production? New Phytol. 170, 201-204.

Bao, X., J. Yu, W. Liang, C. Lu, J. Zhu, and Q. Li, 2015: The interactive effects of elevated ozone and wheat cultivars on soil microbial community composition and metabolic diversity. Appl. Soil Ecol.

$$
87,11-18 .
$$

Biswas, D.K., H. Xu, Y.G. Li, J.Z. Sun, X.Z. Wang, X.G. Han, and G.M. Jiang, 2008: Genotypic differences in leaf biochemical, physiological and growth responses to ozone in 20 winter wheat cultivars released over the past 60 years. Global Change Biol. 14, 46-59.

Burns, R,G., and R.P. Dick, 2001: Enzymes in the Environment: Ecology, Activity and Applications. New York: Marcel Dekker, Inc. p7-22.

Cao, J.L., L. Wang, Q. Zeng, J. Liang, H.Z. Tang, Z.B. Xie, G. Liu, J.G. Zhu, and K. Kobayashi, 2009: 
Chen, W., L.L. Zhang, X.Y. Li, R.Z. Ye, Q. Li, J.G. Zhu, N.N. Fang, L.L. Wang, Z.J. Wu, and W.R. Horwath, 2015: Elevated ozone increases nitrifying and denitrifying enzyme activities in the rhizosphere of wheat after 5 years of fumigation. Plant Soil, 392, 279-288.

Cooperative Research Group on Chinese Soil Taxonomy, 2001: Chinese Soil Taxonomy. China Science and Technology Press, China, pp 221-223.

Dinesh, R., R. P. Dubey, and G. Shyam Prasad, 1998: Soil microbial biomass and enzyme activities as influenced by organic manure incorporation into soils of a rice-rice system. J. Agron. Crop Sci. 181, $173-178$.

Feng, Z.Z., K. Kobayashi, and E.A. Ainsworth, 2008: Impact of elevated ozone concentration on growth, physiology, and yield of wheat (Triticum aestivum L.): a meta-analysis. Global Change Biol.

Grantz, D.A., S. Gunn, and H.B. Vu, 2006: $\mathrm{O}_{3}$ impacts on plant development: a meta-analysis of root/ shoot allocation and growth. Plant Cell Environ. 29, 1193-1209.

Huang, Y., F. Wang, M. Zhong, L. Sui, and W. Wu, 2013: Effects of elevated ozone on carbon, nitrogen content and soil enzymes activities in a winter wheat field. Asian J. Ecotoxicol. 8, 871-878.

Kanerva, T., A. Palojärvi, K. Rämö, K. Ojanperä, M. Esala, and S. Manninen, 2006: A 3-year exposure to $\mathrm{CO}_{2}$ and $\mathrm{O}_{3}$ induced minor changes in soil $\mathrm{N}$ cycling in a meadow ecosystem. Plant Soil 286, $61-73$

Kou, T.J., H.Q. Chang, L.H. Zhang, X.F. Xu, D.Y. Guo, W.L. Zhou, J.G. Zhu, and Y.F. Miao, 2009: Effect of near-surface $\mathrm{O}_{3}$ pollution on terrestrial ecosystems. Ecol. Environ. Sci. 18, 704-710 (in

\section{Chinese).}

Kou, T.J., G.W. Xu, and J.G. Zhu, 2017: Impact of elevated ozone on nutrient uptake and utilization of Chinese Hybrid India rice (Oryza Sativa) cultivars under free-air ozone enrichment. Commun. Soil Sci. Plant Anal. 48, 635-645.

Kou, T.J., W.W. Yu, J.G. Zhu, and X.K. Zhu, 2012: Effects of ozone pollution on the accumulation and distribution of dry matter and biomass carbon of different varieties of wheat. Environ. Sci. 33, 300-305 (in Chinese).

Kou, T.J., L.R. Wang, J.G. Zhu, Z.B. Xie, and Y.L. Wang, 2014: Ozone pollution influences soil 

305-313.

Li, G., S. Wang, Y. Shi, and Chen, X., 2008: Effects of elevated ozone and temperature on soil enzymes activities and phenolic compounds content in spring wheat. J. Agro-Environ. Sci. 27, 121-125 (in Chinese).

Li, Q., X. Bao, C. Lu, X. Zhang, J. Zhu, Y. Jiang, and W. Liang, 2012: Soil microbial food web responses to free-air ozone enrichment can depend on the ozone-tolerance of wheat cultivars. Soil Biol. Biochem. 47, 27-35.

Loya, W., K.S.Pregitzer, N.J. Karberg, J.S. King, and C.P. Giardina, 2003: Reduction of soil carbon formation by tropospheric ozone under increased carbon dioxide levels. Nature 425, 705-707.

McCrady, J.K., and C.P. Andersen, 2000: The effect of ozone on below-ground carbon allocation in wheat. Environ. Pollut. 107, 465-472.

Sami, K.M., K.H. Jaana, R. Riikka, T. Paivi, S. Sanna, S. Jouko, H. Toini, and M. Perttij, 2008: Long-term ozōne effects on vegetation, microbial community and methane dynamics of boreal peatland microcosms in open-field conditions. Global Change Biol. 14, 1891-1903.

Scagel, C.F., and C.P. Andersen, 1997: Seasonal changes in root and soil respiration of ozone-exposed ponderosa pine (Pinus ponderosa) grown in different substrates. New Phytol. 136, 627-643.

Shi, C., F. Ai, C. Wang, C. Wang, S. Yang, and Y. Che, 2016: Effects of elevated atmospheric $\mathrm{CO}_{2}$ and $\mathrm{O}_{3}$ on soil enzyme activities and microbial biomass. J. Agro-Environ. Sci. 35, 1103-1109.

Sitch, S., P.M. Cox, W.J. Collins, and C. Huntingford, 2007: Indirect radiative forcing of climate change through ozone effects on the land-carbon sink. Nature 448, 791-794.

Tang, H.Y., G. Liu, Y. Han, J.G. Zhu, and K. Kobayashi, 2011: A system for free-air ozone concentration elevation with rice and wheat: Control performance and ozone exposure regime. Atmos. Environ. 45, 6276-6282.

Wang, C.Y., Y.M. Bai, J.P. Guo, M. Weng, Z.G. Huo, J.G. Liu, and L. Li, 2004: Impacts of ozone concentration changes on crops and vegetables in China. Acta Meteorologica Sin. 18, 105-116.

Wang, S.G., and Z.Z. Feng, 2006: Effect of elevated atmospheric $\mathrm{O}_{3}$ on arbuscular mycorrhiza L. (AM) and its function. Environ. Sci. 27, 1872-1877 (in Chinese).

Wang, Y.B., S.Y. Wei, Y. Sun, W. Mao, T.T. Dang, W.Q. Yin, S.S. Wang, and X.Z. Wang, 2017: Elevated ozone level affects micronutrients bioavailability in soil and their concentrations in wheat 
268 Zeng, G., J.A. Pyle, and P.J. Young, 2008: Impact of climate change on tropospheric ozone and its 269 global budgets. Atmos. Chem. Phys. 8, 369-387.

270 Zhang, W., H.B. He, Q. Li, C.Y. Lu, X.D. Zhang, and J.G. Zhu, 2014: Soil microbial residue dynamics 271 after 3-year elevated $\mathrm{O}_{3}$ exposure are plant species-specific. Plant Soil 376, 139-149.

272 Zheng, Y., C. Shi, F. Wu, R. Wu, H. Liu, Z. Zhao, and C. Hu, 2009: Effects of simulated elevated atmospheric $\mathrm{O}_{3}$ concentration on soil enzyme activity in winter wheat rhizosphere. Acta Ecologica 274 Sin. 29(8), 4386-4391.

275 Zhu, X.K., Z.Z. Feng, T.F. Sun, X.C. Liu, H.Y. Tang, J.G. Zhu, W.S. Guo, and K. Kabayashi, 2011: 276 Effects of elevated ozone concentration on yield of four Chinese cultivars of winter wheat under fully open-air field conditions. Global Change Biol. 17, 2697-2706.

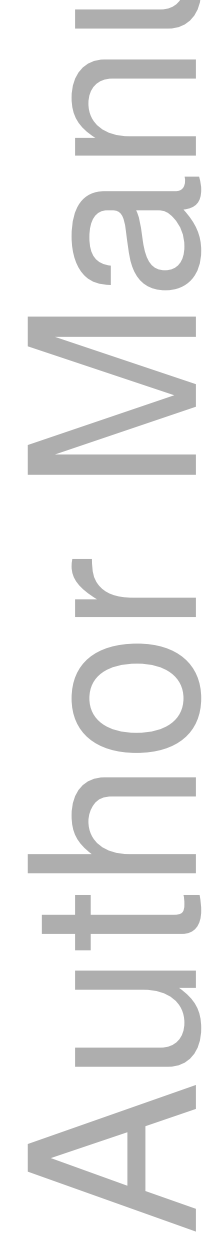


1 Table (1-2):

2 Table 1 Significances of elevated $\mathrm{O}_{3}$ effects on urease and catalase activities in soils under winter wheat

3 cultivars Y15 and YN19

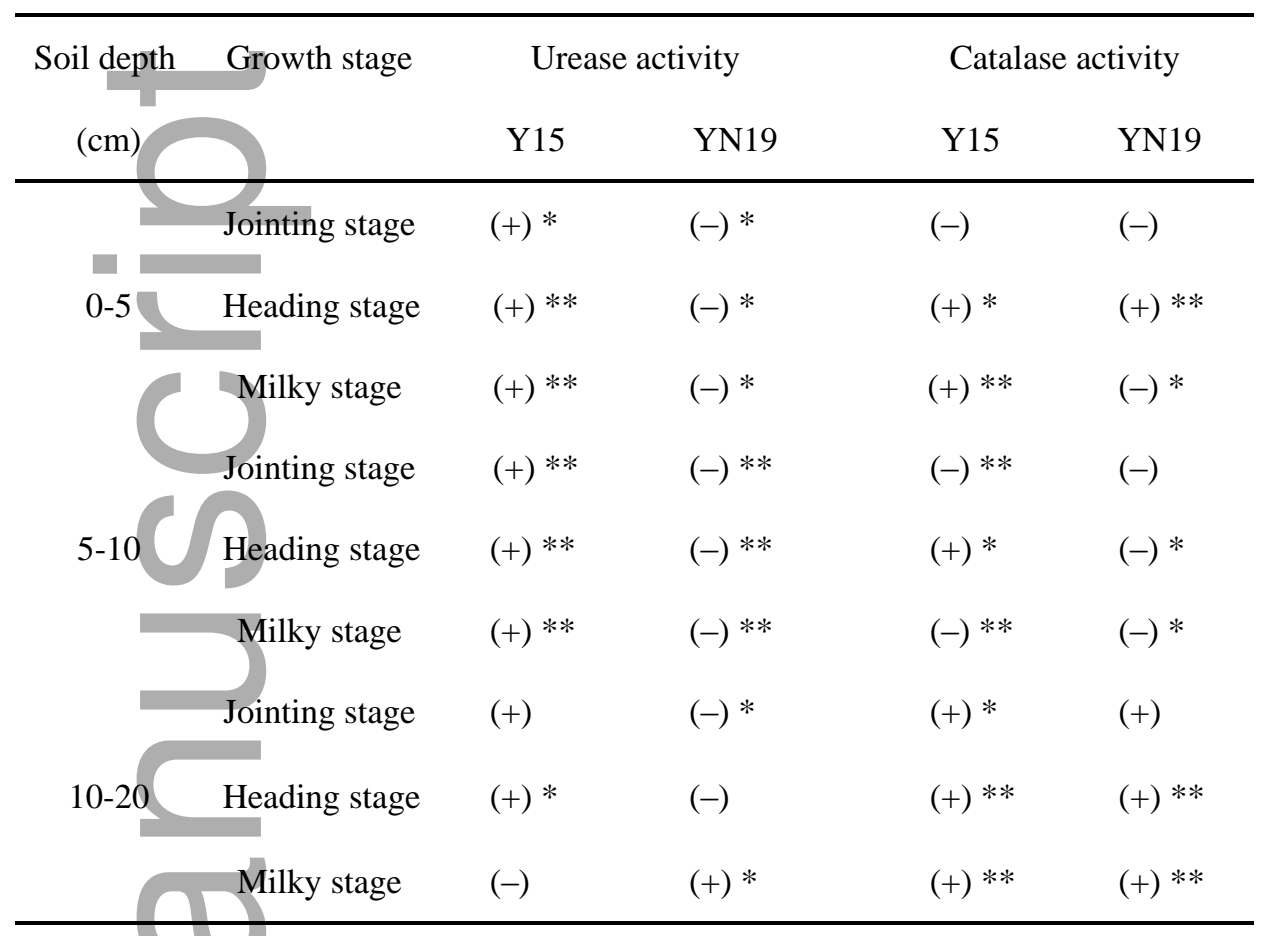

$4(+)$ and $(-)$ refer to the positive and inhibitory effects of elevated $\mathrm{O}_{3}$ on enzymes activities. *, **

5 indicate significant difference at $\mathrm{P}<0.05$ and $\mathrm{P}<0.01$, respectively

6 Table 2 Analysis of variance for urease and catalase activities in response to elevated $\mathrm{O}_{3}$

\begin{tabular}{lcccc}
\hline & \multicolumn{2}{c}{ Urease activity } & \multicolumn{2}{c}{ Catalase activity } \\
Variable source & F value & P value & F value & P value \\
\hline $\mathrm{O}_{3}$ & 13.376 & $<0.001$ & 369.139 & $<0.001$ \\
$\mathrm{Cultivar}(\mathrm{C})$ & 0.417 & $\mathrm{~ns}$ & 4.104 & 0.046 \\
$\mathrm{Soildepth}(\mathrm{D})$ & 258.775 & $<0.001$ & 949.539 & $<0.001$ \\
$\mathrm{Stage}(\mathrm{S})$ & 30.145 & $<0.001$ & 38.889 & $<0.001$ \\
$\mathrm{O}_{3} * \mathrm{C}$ & 74.566 & $<0.001$ & 4.899 & 0.030 \\
$\mathrm{O}_{3} * \mathrm{D}$ & 0.073 & $\mathrm{~ns}$ & 325.61 & $<0.001$ \\
$\mathrm{O}_{3} * \mathrm{~S}$ & 3.479 & 0.036 & 153.942 & $<0.001$ \\
$\mathrm{C} * \mathrm{D}$ & 12.001 & $<0.001$ & 18.599 & $<0.001$ \\
$\mathrm{C} * \mathrm{~S}$ & 4.387 & 0.016 & 2.017 & $\mathrm{~ns}$ \\
$\mathrm{O}_{3} * \mathrm{C} * \mathrm{D}$ & 20.375 & $<0.001$ & 40.13 & $<0.001$
\end{tabular}




$\begin{array}{lcccc}\mathrm{O}_{3} * \mathrm{C} * \mathrm{~S} & 1.838 & \mathrm{~ns} & 14.435 & <0.001 \\ \mathrm{C} * \mathrm{D} * \mathrm{~S} & 3.502 & 0.002 & 37.791 & <0.001 \\ \mathrm{O}_{3} * \mathrm{C} * \mathrm{D} * \mathrm{~S} & 1.387 & \mathrm{~ns} & 26.943 & <0.001\end{array}$

7 ns indicates no significant difference at $\mathrm{P}<0.05$.

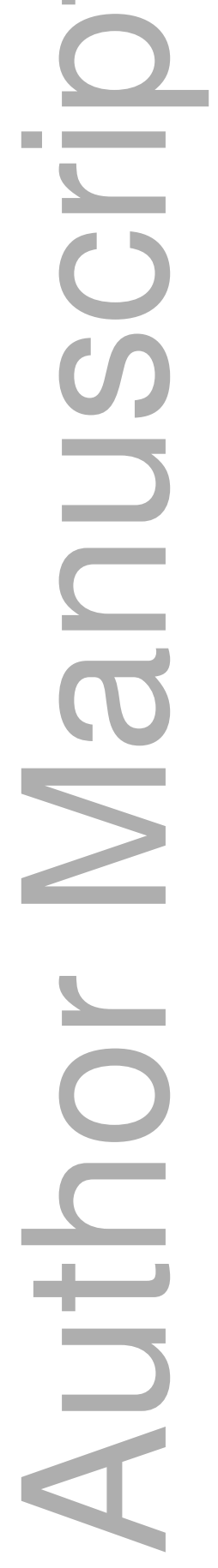


Figure (1-2):

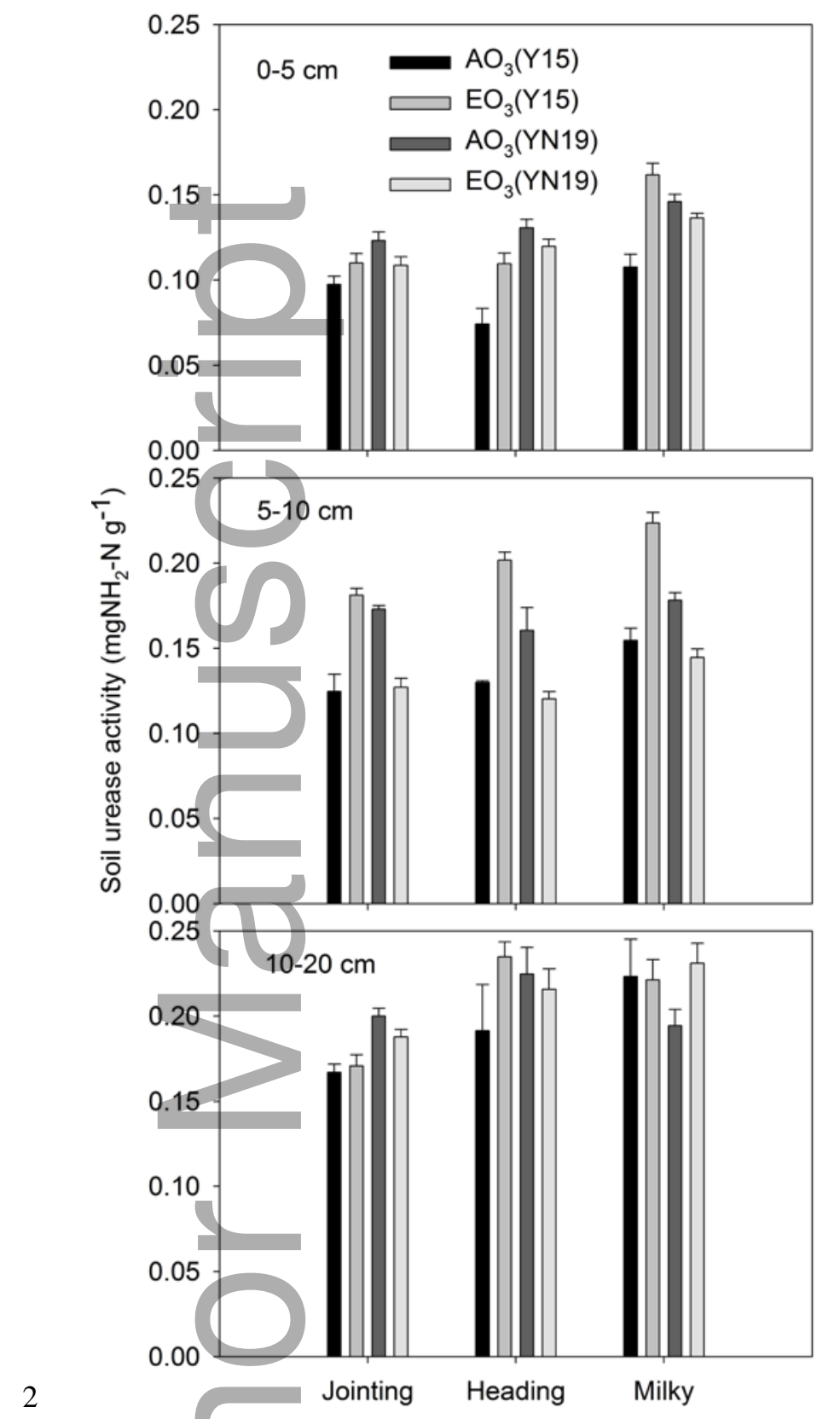

3 Fig. 1 Soil urease activities in topsoil $(0-20 \mathrm{~cm})$ at three key growth stages of two wheat cultivars under

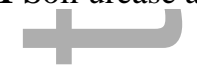

4 elevated $\left(\mathrm{EO}_{3}\right)$ and ambient $\mathrm{O}_{3}\left(\mathrm{AO}_{3}\right)$ concentrations across soil depths. Values are means $\pm 1 \mathrm{SE}(\mathrm{n}=3)$

5

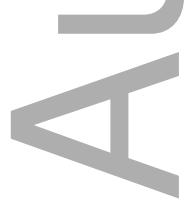

This article is protected by copyright. All rights reserved 

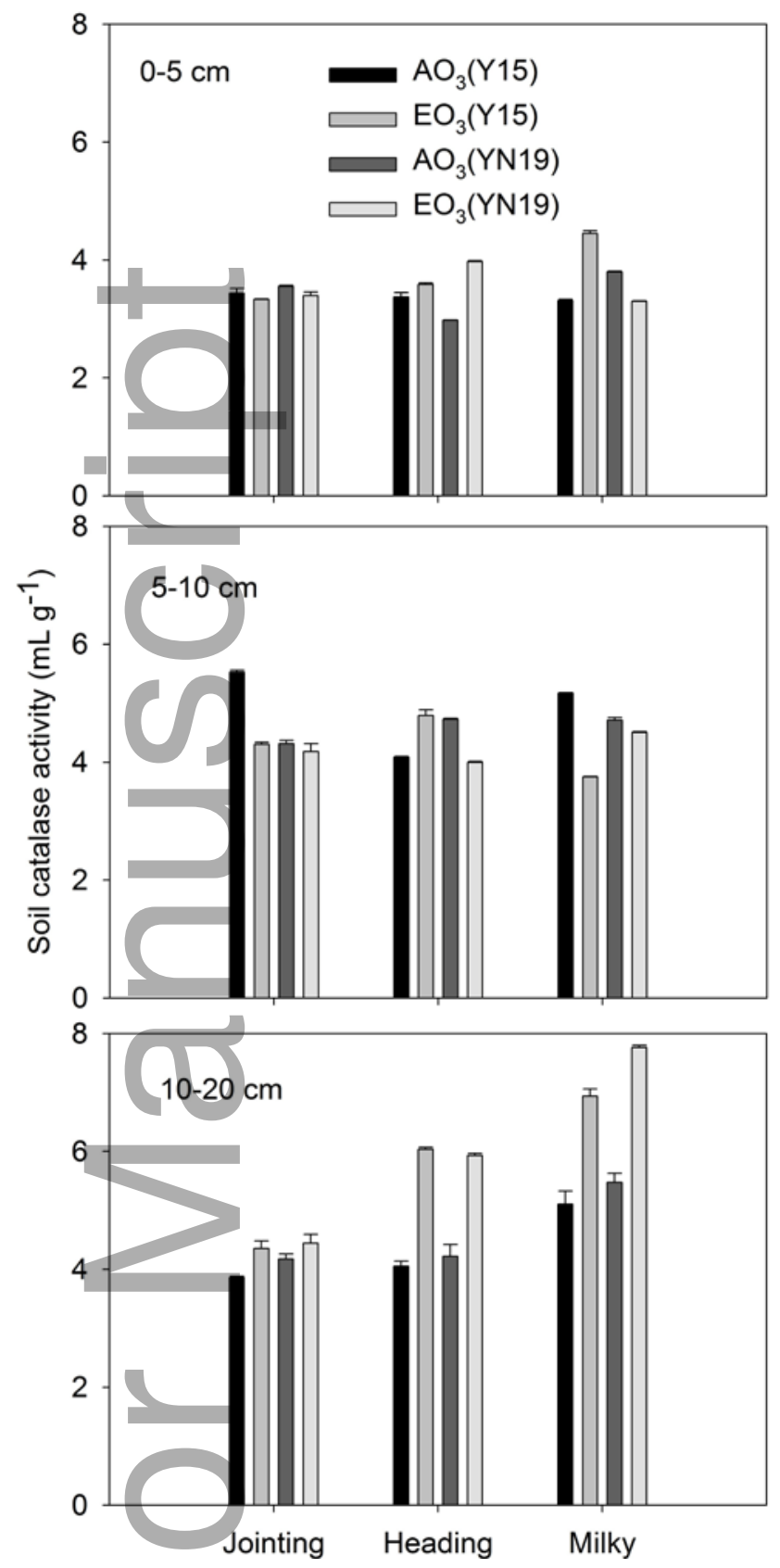

7 Fig. 2 Soil catalase activities in topsoil $(0-20 \mathrm{~cm})$ at three key growth stages of two wheat cultivars

8 under elevated $\left(\mathrm{EO}_{3}\right)$ and ambient $\mathrm{O}_{3}\left(\mathrm{AO}_{3}\right)$ concentrations across soil depths. Values are means $\pm 1 \mathrm{SE}$

$9 \quad(\mathrm{n}=3)$

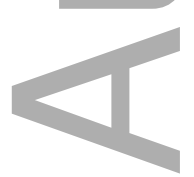




\section{University Library}

\section{- M M N E R VA A gateway to Melbourne's research publications}

Minerva Access is the Institutional Repository of The University of Melbourne

Author/s:

Kou, T-J;Lam, SK;Chen, D-L;Yu, W-W

Title:

Soil urease and catalase responses to ozone pollution are affected by the ozone sensitivity of wheat cultivars

Date:

2018-08-01

Citation:

Kou, T. -J., Lam, S. K., Chen, D. -L. \& Yu, W. -W. (2018). Soil urease and catalase responses to ozone pollution are affected by the ozone sensitivity of wheat cultivars. JOURNAL OF AGRONOMY AND CROP SCIENCE, 204 (4), pp.424-428. https://doi.org/10.1111/jac.12268.

Persistent Link:

http://hdl.handle.net/11343/284124 